\title{
ERITRODERMA YANG DISEBABKAN CUTANEOUS T-CELL LYMPHOMA (CTCL)
}

\author{
Hari Purwanto, Sri Awalia Febriana, Kristiana Etnawati \\ Departemen Ilmu Kesehatan Kulit dan Kelamin \\ FK Universitas Gadjah Mada/RSUP Dr. Sardjito, Yogyakarta
}

\begin{abstract}
ABSTRAK
Eitoderma merupakan peradangan kulit yang mengenai $90 \%$ atau lebih permukaan kulit. Limfoma sel $T$ kulit (cutaneous T-cell lymphoma atau CTCL) merupakan salah satu penyebab eritroderma. Prognosis penyakit ini buruk, karena rerata pasien hanya mampu bertahan 2 tahun, oleh karena itu diagnosis eritroderma karena CTCL menjadi sangat penting.

Seorang lelaki usia 65 tahun datang dengan keluhan utama muncul kulit merah dan mengelupas pada hampir seluruh tubuh sejak 1 bulan sebelum periksa ke rumah sakit. Satu minggu sebelumnya, pasien mengeluh kulit merah dan mengelupas, terasa gatal, badan terasa panas, rambut rontok, kuku menjadi tebal dan kekuningan, demam hingga menggigil. Didapatkan limfadenopati di daerah inguinalis dekstra. Status dermatologis pada hampir seluruh tubuh tampak bercak eritematosa dengan deskuamasi berwarna putih di atasnya, multipel dan tersebar. Pada pemeriksaan darah rutin didapatkan sel Sezary. Hasil pemeriksaan histopatologis menunjukkan sebukan band like sel limfosit atipik di dermis. Selain itu didapatkan juga mikroabses Pautrier. Pengecatan imunohistokimia CD3 + dan CD4+ menunjukkan hasil positif. Lesi membaik dengan terapi injeksi metilprednisolon intravena $62,5 \mathrm{mg} /$ hari selama 7 hari.

Penyebab eritroderma pada kasus ini adalah CTCL yang ditegakkan dengan anamnesis, pemeriksaan fisis dan penunjang terutama darah lengkap dan pemeriksaan histopatologis.
\end{abstract}

Kata kunci: eritroderma, $C T C L$

\section{ERYTHRODERMA DUE TO CUTANEOUS T-CELL LYMPHOMA (CTCL): CASE REPORT}

\begin{abstract}
Erythroderma is a skin inflammation that is about $90 \%$ or more on the surface of the skin. Cutaneous T-cell lymphoma accounts for a minority of cases of erythroderma. Prognosis is poor with median survival of approximately 2 years, so diagnosing erythroderma caused by CTCL is really important.

Case A 65-years-old man with a chief complaint red and scaly skin on the almost entire body a month prior to check into the hospital. In past history a week hospitalization, the patient complained of skin became red and scaly, itchy, hair loss, nail becomes thick and yellowish, accompanied by fever and shiver. Skin examination in almost entire body showed discrete multiple erythematous patch with white scale above with right inguinl lymphadenopathy. Routine blood tests showedSezary cells. Histopathological examination showed band like cell infiltration of atypical lymphocytes in the dermis, and Pautrier's microabscesses. Immunohistochemical examination with $C D 3$ and $C D 4$ staining showed positive results. Lesions improved with therapy of intravenous methylprednisolone 62,5mg per day for a week.

Discussion In this case we diagnosed patient with erythroderma caused by CTCL based on history, physical examination, blood tests and immunohistopathological features.
\end{abstract}

Key words: erythroderma, $C T C L$

Korespondensi:

Jl. Farmako Sekip, Gedung Radiopoetra Lt.3,

Yogyakarta 55281

Telp: 0274-560700

Email: liamvicena@gmail.com 


\section{PENDAHULUAN}

Eritoderma berasal dari bahasa Yunani erythro ( $\mathrm{red}=$ merah)dan derma,dermatos ( $k$ in $=$ kulit),merupakan peradangan kulit yang mengenai $90 \%$ atau lebih permukaan kulit, dan dapat disertai skuama. ${ }^{1}$ Pada beberapa kasus, skuama tidak selalu ditemukan, misalnya pada eritroderma yang disebabkan oleh alergi obat secara sistemik. Pada eritroderma proses kronik, eritema tidak begitu jelas, karena bercampur dengan hiperpigmentasi. Nama lain penyakit ini adalah dermatitis eksfoliativa generalisata, meskipun sebenarnya mempunyai pengertian yang agak berbeda. ${ }^{2}$ Kata 'eksfoliasi' berarti pengelupasan skuama yang terjadi, walaupun terkadang tidak begitu terlihat, dan kata 'dermatitis' berdasarkan reaksi eksematosa. ${ }^{3}$ Eritroderma dapat timbul sebagai perluasan dari penyakit kulit yang telah ada sebelumnya (psoriasis, dermatitis atopik dan dermatosis spongiotik lainnya), reaksi hipersensitivitas obat (antiepilepsi, antihipertensi, antibiotika, calcium channel blocker, dan bahan topikal), penyakit sistemik termasuk keganasan, serta idiopatik $(20 \%)^{4,5}$

Insidens eritroderma di Amerika Serikat bervariasi, antara 0,9 sampai 71,0 per 100.000 pasien rawat jalan dermatologi. Hasan dan Jansen (1983) memperkirakan insidens eritroderma sebesar 1-2 pasien per 100.000 pasien. Sehgal dan Srivasta (1986) pada sebuah penelitian prospektif di India melaporkan 35 per 100.000 pasien eritroderma di rawat jalan dermatologi. Pada beberapa laporan kasus, didapatkan insidens pada lelaki lebih besar daripada perempuan, dengan proporsi 2:1 sampai 4:1, dan rerata usia 41-61 tahun. ${ }^{6-8}$ Angka kematian bergantung pada penyebab eritroderma. Sigurdson (1996) melaporkan dari 102 pasien eritroderma terdapat 43\% kematian, 18\% disebabkan langsung oleh eritroderma dan $74 \%$ tidak berhubungan dengan eritroderma. ${ }^{9}$

Limfoma sel T kulit (cutaneous T-cell lymphoma atau CTCL) merupakan kelompok kelainan limfoproliferatif heterogen yang ditandai oleh akumulasi klonal limfosit $\mathrm{T}$ neoplastik di kulit. Insidensinya lebih tinggi pada kelompok Afrika-Amerika, dan lebih banyak pada lelaki dibandingkan dengan perempuan. CTCL merupakan salah satu penyebab eritroderma. Meskipun tidak selalu ditemukan di semua subtipe CTCL, hal itu merupakan ciri dari eritroderma mikosis fungoides dan Sezary Syndrome (SS). Insidensi CTCL selama tahun 20002010 mencapai 10 kasus per satu juta orang per tahun di Amerika Serikat. ${ }^{10}$

Jumlah kasus sejak 1 Januari 2013-1 Januari 2017 di Poliklinik Dermatologi dan Veneorologi RSUP dr. Sardjito didapatkan 10 pasien dengan diagnosis CTCL. Diagnosis eritroderma karena CTCL ditegakkan berdasarkan anamnesis, gambaran klinis, dan pemeriksaan laboratorium dan pemeriksaan histopatologis. Diagnosis akurat penyakit ini merupakan proses yang sistematis membutuhkan pengamatan yang seksama, evaluasi serta pengetahuan tentang terminologi dermatologi, morfologi, serta diagnosis banding.

Penyakit ini biasanya agresif dan prognosis umumnya buruk dengan rerata lama hidup 2-4 tahun. Pasien mungkin merespons terapi hanya sementara, namun kekambuh sering tidak terelakkan. Pasien sering mengalami remisi setelah pengobatan. Pasien biasanya meninggal karena infeksi oportunistik akibat penurunan kekebalan tubuh.

Tujuan penulisan makalah ini adalah agar klinisi terutama dokter spesialis kulit dan kelamin jika mendapatkan pasien eritroderma agar melakukan pemeriksaan penunjang di antaranya pemeriksaan darah dan histopatologis untuk memastikan diagnosis dan penyebabnya sehingga penatalaksanaan pasien dengan eritroderma lebih tepat dengan penyakit yang mendasari.

\section{KASUS}

Seorang lelaki berusia 65 tahun, bekerja sebagai petani, berdomisili di Gunung Kidul, datang ke IGD RSUP dr.Sardjito pada tanggal 5 November 2016, dengan keluhan utama muncul kulit merah dan mengelupas pada hampir seluruh tubuh. Satu bulan sebelum periksa ke rumah sakit, pasien mengeluh kulit kering, gatal, bersisik pada hampir seluruh tubuh. Pasien berobat ke spesialis kulit dan kelamin di RSUD Wonosari dengan diagnosis kerja sebagai penyakit kulit akibat sinar matahari, mendapatkan terapi berupa kapsul dengan nama dan kandungan tidak diketahui dan minyak oles, namun keluhan tidak membaik. Satu minggu sebelum periksa ke rumah sakit, pasien mengeluh kulit merah dan mengelupas, terasa gatal, badan terasa panas, rambut rontok, kuku menjadi tebal dan kekuningan, demam dan menggigil terutama setelah mandi. Pasien periksa ke dokter umum dengan diagnosis tidak diketahui dan mendapat terapi berupa 3 macam tablet yang tidak diketahui namanya, diminum 2 kali sehari dan pasien mengaku tidak membaik.

Duapuluh tahun sebelumnya pasien mengeluh timbul bercak-bercak merah di tungkai saat bekerja di proyek, terasa gatal namun tidak demam. Kemudian pasien periksa ke dokter umum dengan diagnosis dan terapi tidak diketahui, pasien merasa sembuh namun penyakit kambuh-kambuhan. Pasien merasa alergi dengan daun padi dan jagung. Riwayat hipertensi sejak 15 tahun yang lalu, rutin kontrol ke dokter umum dengan obat tidak diketahui.

Pada pemeriksaan fisik didapatkan keadaan umum sedang, kesadaran compos mentis dan pemeriksaan tanda vital menunjukkan hasil normal. Didapatkan limfadenopati pada inguinalis dekstra berukuran $3 \mathrm{~cm}$, dapat digerakkan, tidak didapatkan nyeri tekan. Status dermatologis pada hampir seluruh tubuh tampak bercak 
eritematosa multipel-diskret, dengan skuama berwarna putih di atasnya. Kelopak mata tampak ektropion, kuku tampak diskolorisasi (berubah warna menjadi kuning kecoklatan) dan hiperkeratosis.
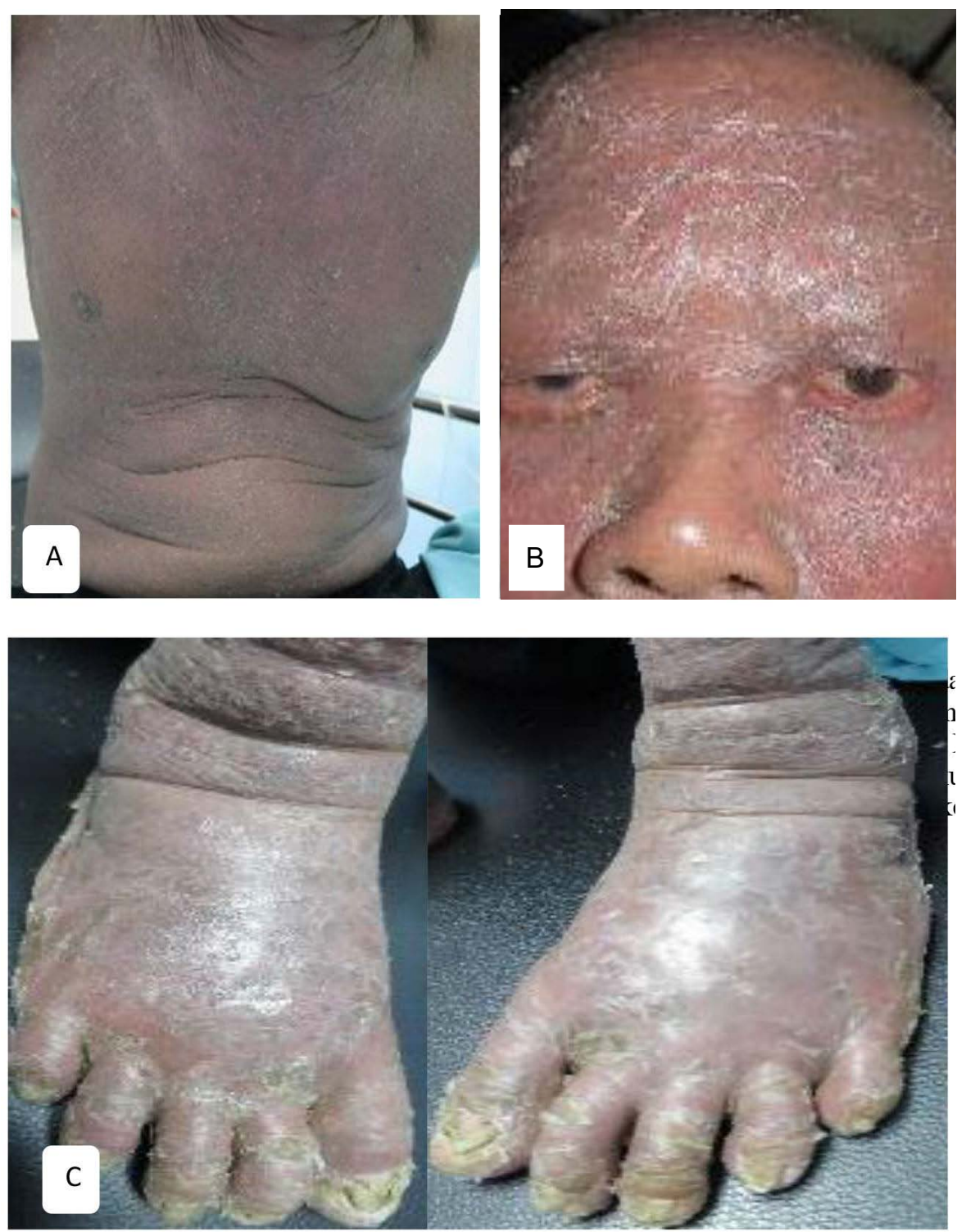

Gambar 1. A. pada hamper seluruh tubuh tampak eritematosa dengan skuama tebal berwarna putih, B. palpebra okuli tampak ektropion,

C. kuku tampak iskolorisasi dan hiperkeratosis subungual.

Diagnosis banding kasus ini ialah eritroderma akibat dermatitis kontak alergi (DKA), dermatitis kontak iritan (DKI) dan eritroderma psoriatika. Berbagai pemeriksaan penunjang dilakukan untuk menegakkan diagnosis. Pemeriksaan darah rutin dan kimia darah didapatkan sel Sezary dalam 3 hari pemeriksaan berturut-turut, albuminemia dan peningkatan kadar kreatinin dan asam urat. Fungsi hepar dan elektrolit dalam batas normal.
Biopsi dilakukan dengan sampel kulit diambil pada tepi bercak eritematosa yang terdapat deskuamasi. Berdasarkan hasil pemeriksaan histopatologis dengan pengecatan HE didapatkan sebukan sel limfosit atipik tersusun band like pada dermis, selain itu didapatkan juga mikroabses Pautrier. Pengecatan imunohistokimia CD3 dan CD4 menunjukkan hasil positif, terdapat infiltrat limfosit atipik yang lebih menyerap warna kecoklatan, sebukan sel tampak pada lapis dan dermis hingga sebagian epidermis. 

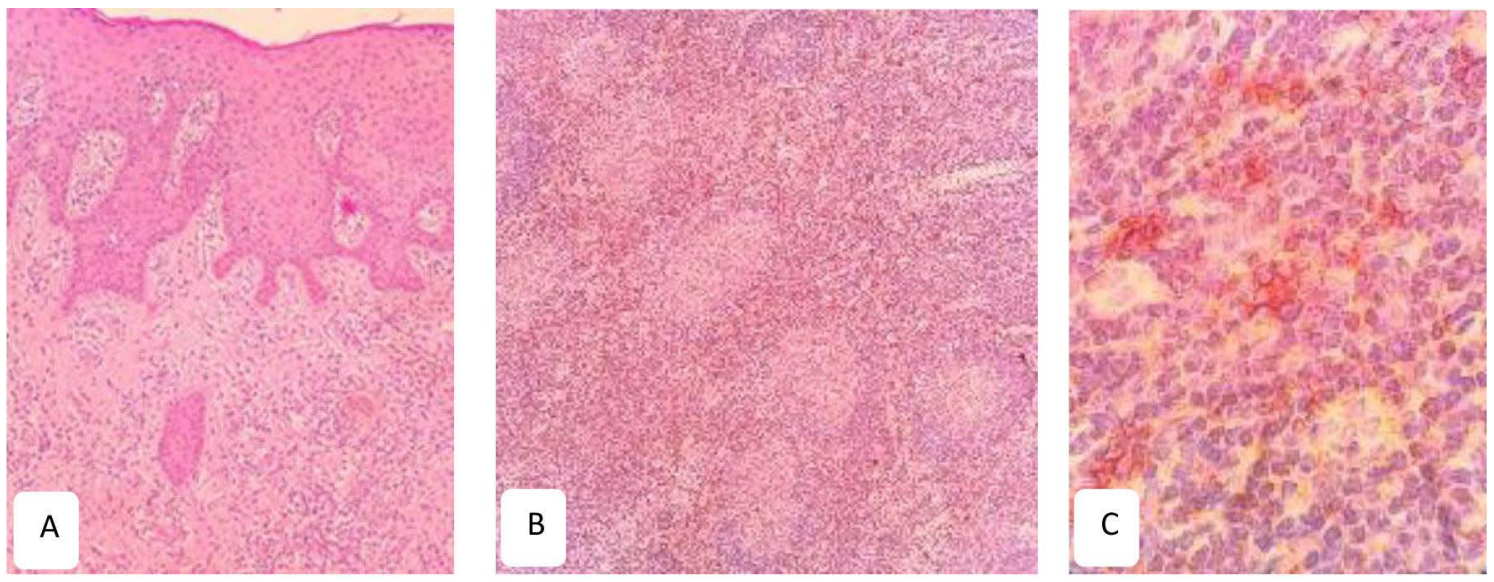

Gambar 2. A). pada epidermis dan dermis tampak sebukan limfosit yang tersusun band like.

B). pada pengecatan imunohistokimia positif untuk CD3 dan CD4.

C). pengecatan imunohistokimia $\mathrm{CD}^{+}$dan $\mathrm{CD}^{+}$(pembesaran 10x100)

Diagnosis kerja yang ditegakkan berdasarkan hasil anamnesis, pemeriksaan fisik, pemeriksaan darah dan gambaran histopatologis dan pengecatan imunohistokimia sesuai dengan eritroderma karena CTCL. Selama perawatan di bangsal, pasien di terapi dengan injeksi metilprednisolon $62,5 \mathrm{mg} /$ hari, cetirizin tablet $1 \times 10$ $\mathrm{mg}$, topikal inerson 30 gram ditambah gliserin 5\% dalam oleum cocos $100 \mathrm{cc}$ dioleskan dua kali sehari. Selama perawatan 7 hari terdapat perbaikan lesi kulit pasien, yaitu eritema dan deskuamasi tidak lagi ditemukan pada akhir perawatan. Pasien dijadwalkan kontrol poli untuk penatalaksanaan lanjutan CTCL.

\section{PEMBAHASAN}

Eritroderma dapat timbul sebagai perluasan penyakit kulit yang telah ada sebelumnya. Kondisi yang sering menimbulkan eritroderma antara lain psoriasis, dermatitis atopik, dermatitis seboroik, reaksi hipersensitivitas obat, serta keganasan termasuk CTCL. Psoriasis ialah penyakit autoimun, bersifat kronis dan residif, yang ditandai dengan banyak plakeritematosa berbatas tegas dengan skuama yang kasar, berlapis-lapis dan transparan. Dermatitis atopik adalah dermatitis yang terjadi pada orang yang mempunyai riwayat atropi, ditandai dengan reaksi yang berlebihan terhadap rangsangan lingkungan, misalnya bahan iritan, alergen, dan kecenderungan peningkatan IgE. Gejala utama berupa rasa gatal, eritematosa dan perubahan histopatologis dengan sel radang yang bulat, dan ditemukan spongiotis di epidermis. Dermatitis seboroik adalah peradangan yang sering terdapat pada daerah sebore, terutama kulit kepala, alis mata dan wajah, kronis dan superfisial. Pada reaksi hipersensitivitas obat, beberapa obat misalnya golongan calcium channel blocker, antiepilepsi, antibiotik (antara lain penisilin, sulfonamid, dan vankomisin), alopurinol, lithium quinidine, simetidin dan dapson adalah obat yang sering mencetuskan eritroderma. Penyakit keganasan yang dapat menimbulkan eritroderma adalah limfoma dan leukemia. CTCL atau sindrom Sezary, termasuk limfoma, merupakan stadium dini mikosis fungoides yang penyebabanya belum diketahui, dan diduga akibat infeksi virus.

Eritroderma jarang disebabkan oleh penyakit imunobulosa, penyakit jaringan ikat, infeksi yang meliputi skabies dan dermatofita, pitriasis rubra pilaris (PRP) atau penyakit keganasan. ${ }^{10-12}$ Upaya penegakan diagnosis penyebab eritroderma sangat penting karena jika hanya berdasarkan klinis semata, terutama dalam penegakan diagnosis eritroderma karena CTCL bahkan sering salah diagnosis dengan penyebab lain atau dikatakan eritroderma idiopatik.

Makalah ini melaporkan sebuah kasus eritroderma akibat CTCL yang terjadi pada lelaki berusia 65 tahun, dengan pertimbangan sesuai usia rerata awitan di atas 60 tahun. ${ }^{13,14}$

Manifestasi klinis pasien dengan eritroderma akibat CTCL adalah plak eritematosa difus, menebal dan bersisik. Pruritus merupakan gejala yang umum, sering parah hingga mengganggu siklus tidur bahkan menyebabkan depresi.9,11 Gejala lain yang dapat ditemukan antara lain indurasi kulit yang terjadi secara perlahanlahan, likenifikasi (terjadi akibat garukan dan gosokan), papul folikular yang berskuama, penebalan kuku, ektropion, dan alopesia. Selain itu dapat juga dijumpai gejala sistemik berupa limfadenopati perifer, terutama di leher, aksila, dan lipat paha. Dapat juga dijumpai pembesaran limpa. Hepar, paru dan saluran cerna jarang terpengaruh. ${ }^{12,13,15}$

Pada kasus ini didapatkan keluhan pasien berupa kulit merah dan mengelupas pada hampir seluruh tubuh, terasa sangat gatal, rambut rontok, kuku jari tangan dan 
kaki menebal. Pada pemeriksaan klinis didapatkan lesi kulit pada hampir seluruh tubuh berupa makula, bercak dan plak eritematosa multipel tersebar disertai skuama warna putih, tebal, multipel tersebar. Pada kuku tampak hiperkeratosis. Pada palpebra okuli dekstra dan sinistra didapatkan ektropion. Pada palpasi didapatkan pembesaran limfonodi inguinalis dekstra.

Pasien ini didiagnosis banding dengan eritroderma akibat DKI/DKA berdasarkan keluhan gatal pada lesi setelah kontak dengan daun padi dan jagung dan bersifat kambuhan. Pertimbangan diagnosis eritroderma psoriatika karena pada pasien ini ditemukan plak eritematosa dengan skuama tebal berwarna putih, meskipun keluhan serupa sebelumnya disangkal. ${ }^{16}$

Gambaran histopatologis sesuai dengan eritroderma akibat CTCL, yaitu didapatkan sebukan limfosit atipik dermis, epidermotropisme (sel bermigrasi ke epidermis), limfosit dengan bentuk inti serebriformis, mikroabses Pautrier, pengecatan imunohistokimia positif untuk sel $\mathrm{CD}^{+}$dan CD4. ${ }^{+8,14,17}$ Hasil pemeriksaan histopatologis pada pasien ini didapatkan sebukan sel limfosit atipik yang tersusun band like pada dermis, selain itu didapatkan juga mikroabses Pautrier. Berdasarkan hasil tersebut

\section{DAFTAR PUSTAKA}

1. Wollina U. Cutaneous T cell lymphoma: update on treatment. Int J Dermatol.2012; 51:1019-3

2. Assaf C, Sterry W. Cutaneous lymphoma. Dalam: Wolff K, Goldsmith LA, Katz SI, Gilcherst BA, Paller AS, Leffell DJ, penyunting. Fitzpatrick's dermatology in general medicine. Edisi ke-8. New York: McGraw-Hill Companies; 2008.h.1386.

3. Sikorska M, Sokolowska_Wojdylo M, Kowalczyk A, Roszkiewicz J. Effectiveness of interferon in mycosis fungiodes therapy. Post Dermatol Alergol. 2012; 29: 51-5

4. Prince HM. New strategies in the treatment of T-cell lymphoma. Clin Adv Hematol Oncol. 2008;6:4-10.

5. Kim YH. Cutaneous T-cell lymphoma facts. Canada: Leukemia and lymphoma Society; 2011.h.1-9.

6. Willerslev-Olsen A, Kresjgaard T, Lindahl LM, Bonefeld CM, Wasik MA, Koralov SB, dkk. Bacterial toxins fuel disease progression in cutaneous T-cell lymphoma. Toxins. 2013;5:1403-20.

7. Sapadin AN, Fleischmajer R. Tetracyclines: nonantibiotic properties and their clinical implications. J Am Acad Dermatol. 2006;54:258-63.

8. Meyer N, Paul C, Misery L. Pruritus in cutaneous T-cell lymphomas: frequent, often severe and difficult to treat. Acta Dermatol Venereol. 2010;90:12-7.

9. Rothe MJ, Bernstein ML, Grant-Kels JM. Life-threatening erythroderma: diagnosing and treating the "red man". Clin Dermatol.2005;23(2):206-17 ditegakkan diagnosis eritroderma karena CTCL.

Alasan pemberian terapi steroid sistemik pada pasien ini adalah untuk mengatasi eritroderma karena hasil histopatologis baru diperoleh satu minggu kemudian. Setelah perawatan, pasien kontrol di poliklinik kulit RSUP Dr.Sardjito sebanyak dua kali. Lesi kulit membaik dan steroid sistemik diturunkan bertahap dan terapi topikal dilanjutkan. Namun pasien tidak kontrol kembali dan tidak dapat dihubungi sehingga pasien belum mendapatkan terapi definitif, yaitu obat kemoterapi.

\section{SIMPULAN}

Makalah ini melaporkan sebuah kasus dengan eritroderma akibat penyakit yang mendasarinya yaitu CTCL. Para klinisi khususnya spesialis kulit dan kelamin harus melakukan pemeriksaan histopatologiss dalam menetapkan penyebab eritroderma, agar tidak terjadi kesalahan diagnosis dengan penyakit yang lain sehingga penatalaksanaan dan hasil luaran yang didapatkan menjadi lebih optimal. Diagnosis eritroderma karena CTCL dapat ditegakkan berdasarkan anamnesis, pemeriksaan fisik dan pemeriksaan penunjang terutama sel Sezary dan pemeriksaan imunohistokimia.

10. Sigurdsson VS, Toonstra J,Hezemans-Boer M, van Vloten WA. Erythroderma. Elsevier 1996;35(1):53-7

11. Willemze R, Jaffe ES, Burg G. WHO-EORTC classification for cutaneous lymphomas. J Cutan Pathol 2005;32(10):64774

12. Agar NS, Wedgeworth E, Crichton S, Tracey JC, Michael F, Silvia R, dkk. Survival outcomes and prognostic factors in mycosis fungoides/sezary syndrome: validation of the revised international society for cutaneous lymphomas/European organisation for research and treatment of cancer staging proposal. J Clin Oncol. 2010;28(31):4730-9

13. Wieselthier JS, Koh HK. Sezary syndrome:diagnosis, prognosis, and critical review of treatment options. J Am Dermatol.1990;22(3):381-401

14. Yamaguchi T, Ohshima K, Karube K, Tutiya T, Kawano R, Suefuji H, dkk. Clinicopathological features of cutaneous lesions of adult T-cell leukaemia/lymphoma. Br J Dermatol. 2005;152(1):76-81

15. Cho-Vega JH, Tschen JA, Duvic M,Vega F. Early-stage mycosis fungoidesvariants: case-based review. Ann DiagnPathol. 2010;14(5):369-85

16. Gelfand JM, Shin DB, Neimann AL, Wang X, Margolis DJ, Troxel AB.The risk of lymphoma in patients with psoriasis. J Invest Dermatol. 2006;126(10):2194-201

17. Ahern K, Gilmore ES. Pruritus in cutaneousT-cell lymphoma: a review. J Am Acad Dermatol. 2012;67(4):760-8 